\title{
A Gravity Model Approach towards Pakistan's Bilateral Trade with SAARC Countries
}

\author{
Waheed Ullah Jan \\ Ph.D. Research Scholar, Department of Economics, Gomal University \\ Dera Ismail Khan, Pakistan, e-mail: janwaheed77@gmail.com
}

\section{Mahmood Shah}

Associate Professor, Department of Economics, Gomal University

Dera Ismail Khan, Pakistan, e-mail: moodishahji@yahoo.com

\begin{abstract}
This research paper attempts to estimate the bilateral trade of Pakistan with SAARC countries using a gravity model of trade. This panel study covers the period from 2003 to 2016. The empirical results are obtained through pooled OLS, fixed-effects, and random-effects estimators. On the basis of Hausman test results, the paper concentrates only on the findings of the fixed-effects model. The empirical findings reveal that the GDPs of both Pakistan and the partner country have a positive impact on bilateral trade. Market size has a negative impact on trade and this is justified on the basis of the absorption effect. Similarly, distance and exchange rate also have a negative correlation with bilateral trade. The study finds that Pakistan has very low trade with India and Afghanistan, despite the common border. A common language has a positive but insignificant impact on Pakistan's bilateral trade. The Paper also attempts to calculate the trade potential of Pakistan. The findings reveal that Pakistan has high trade potential with all SAARC member countries except the Maldives and Afghanistan.
\end{abstract}

Keywords: bilateral trade, common language, exchange rate, gravity model, population

JEL: F14, F15, F31, F53 


\section{Introduction}

The exchange of goods for the purpose of trade between two countries is termed bilateral trade. In bilateral trade, the partner countries try to eliminate tariffs and other trade barriers to facilitate and encourage bilateral activities. Additionally, bilateral trade agreements and their implications, mobility of labor and increasing access to foreign markets are a focus in bilateral trade. The main objective of bilateral trade is to achieve persistent economic growth and development along with poverty alleviation and jobs creation. Pakistan has established bilateral trade relations with a number of countries around the world.

The South Asian Association for Regional Cooperation (SAARC) was formed in 1985. At the initial stage it was a set of seven nations (India, Pakistan, Bangladesh, Sri Lanka, Nepal, Bhutan, and the Maldives), but later on, Afghanistan joined this group. Now, SAARC comprises eight countries. Since the birth of SAARC, the member countries have struggled towards regional cooperation and economic assimilation. In April 1993, the SAARC countries signed a trade agreement called the South Asian Preferential Trading Agreement (SAPTA). This agreement was a milestone for the economic assimilation of the SAARC member countries. The agreement was made operational in December 1995. Furthermore, in 2004, SAARC member countries signed another agreement, called the South Asian Free Trade Area (SAFTA). This agreement was made applicable in 2006. The main objective of this agreement was to declare South Asia a free trade area by the end of 2016 (Hassan and Rehman 2015).

Trade relations between Pakistan and South SAARC countries are not new phenomena. After independence, Pakistan established trade relations with neighboring countries as well as other countries of the region. These relations accelerated in the 1990s when the global trade scenario was changing. Since then, Pakistan has been very keen to expand its trade with countries in the region and has signed various trade agreements with the regional and neighboring countries. The outcome of these agreements is that tremendous enhancement has been seen in the trade pattern of the region and a significant increase in exports has been observed. Pakistan has been following export-based policies since 2000/01. Obviously, the achievements of these policies depend upon the access of Pakistan's products to the worldwide markets. Pakistan has made serious efforts for the improvement of global trade, but still, its import and export volume is not remarkable with SAARC countries. Politics and the interference of the armed forces in government policies are the key hurdles in the way of regional trade (Gul and Yasin 2011).

SAARC countries have faced many developmental obstacles. Large fiscal deficits were observed in Pakistan, India, and Sri Lanka. Similarly, a high degree of corruption in Bangladesh, the civil war in Sri Lanka, macroeconomic volatility in Nepal, the Maldives, and Bhutan, and the lack of tolerance and political hostility between the two neighboring countries of India and Pakistan have significantly slowed down their economic development and regional collaboration. However, these challenges were suc- 
cessfully overcome. Sri Lanka brought liberalization to their trade policies. India and Sri Lanka took initiatives to liberalize trade and deregulate interest rates, and the same path was followed by Pakistan and Bangladesh. Despite these reforms, however, Pakistan's bilateral trade with the SAARC region is not encouraging. It was about 8 percent of its overall trade in 2010-11. This trading level is extremely disappointing compared to the trade activities of other regional groups like ASEAN. In 2010-2011, Pakistan's bilateral trade with India, Bangladesh, and Sri Lanka was 2.7 percent, 1.6 percent and 0.61 percent respectively (Akram 2013).

Pakistan and the other SAARC countries have realized the importance of intraregional trade. Thus, they have adopted open trade policies to achieve positive consequences of bilateral trade. The recent scenario of international trade shows that bilateral or regional grouping trade on a preferential basis can play a significant part in imports and exports of goods and services. However, SAARC countries are facing some difficulties in the regional integration process. First, there is a shortage of transparent policies for the betterment of upcoming economic integration and social wellbeing. Second, some problems happen due to tariff-related constraints that limit awareness about economic integration. Finally, structural backwardness and economic deficiencies in the region aggravate the situation.

The foremost objective of this research paper is to highlight the major determinants of Pakistan's bilateral trade with the SAARC region. The other main objectives of the study are: 1) To estimate the bilateral trade flow between Pakistan and SAARC countries. 2) To find the degree of trade integration via a Gravity Model with neighboring countries. 3) To determine the trade potential of Pakistan with the other SAARC countries.

The rest of the paper is arranged as follows. Section two contains relevant literature to the study. The third section consists of research methodology. The fourth section contains the empirical results and in the last section, conclusions are drawn.

\section{Review of the literature}

This section consists of empirical studies based on the gravity model conducted by previous researchers. It provides a roadmap for the application of the gravity model in bilateral trade for the current study.

Kaur and Nanda (2010) examined the trade relations between India and SAARC countries. In this regard, they took exports of India as the dependent variable. All seven member countries of SAARC were observed and Panel data were collected for the period 1981-2005. They ran the gravity model and estimated the results by applying three methods: random effects, fixed effects, and pool estimation. From the empirical results, they concluded that India has excellent trade opportunities with SAARC countries, especially Pakistan, Bhutan, and Nepal. Moreover, India's exports can be extended to SAARC markets if they remove mutual barriers on trade because 
India borders four SAARC member countries. The geographical location of India will favor their trade.

Sherif and Fantazy (2013) analyzed the trade among the Gulf countries (Kuwait, Qatar, UAE, Oman, Bahrain and Saudi Arabia) fitting the Gravity Model to the Panel data. The results of the gravity model assigned expected signs to all the variables of the gravity model. Economic size (GDP), market size (population), and GDP per capita have a significant and positive impact on the export pattern of Saudi Arabia. Distance has a normal effect on Saudi Arabia's exports, as suggested by gravity theory. Its impact is negative on Saudi Arabia's exports. Hence, it is proved that the factors of the gravity model truly explain the volume of bilateral trade.

Shujaat (2015) examined Pakistan's bilateral trade with 140 countries by using the augmented gravity model and random effects methodology. Along with basic variables, the researcher incorporated inflation rate, common language, free trade agreements, supply capability, and demand potential as independent variables in the gravity model. The results exposed the fact that distance (transportation cost) has no effect on Pakistan's bilateral trade. Similarly, Pakistan's inflation rate and supply capabilities were also found in the critical form. The basic variable (GDP) was found to be a reliable factor in Pakistan's bilateral trade. Estimates of the gravity model suggested that free trade agreements are not in favor of Pakistan. Their impact is negative on Pakistan's bilateral trade.

Panda and Kumaran (2016) attempted to investigate the trade volume between China and India by applying the gravity model. They estimated the results through a random-effects model (Panel regression model). Their results show that the trade level between the two countries will be higher than between countries that lie far away from each other. According to their research, the trade volume between China and India will flourish because of the small distance between them. India's bilateral trade is highly predisposed by China's economic size (GDP) and language similarities, while this trade decomposed with low-income countries.

Wang (2016) researched eighty countries and used panel data for the period 20002013. For analysis, the gravity model of trade was fitted to the data through the PPML technique. The results fully supported the assumptions of the gravity model and suggested that economic mass and bilateral trade have a positive relationship, while distance creates negative shocks on mutual trade between two countries.

Hussain (2017) examined the factors affecting Pakistan's exports with the help of the gravity model. The researcher used panel data and selected the period from 1993-2013. For analytical estimation, the author used a relatively new technique, called the PPML estimator, which is consistently used with a gravity model to tackle the problems of panel data. The empirical findings of the study confirmed the theoretical structure of the gravity model. It was established that distance has a negative impact on Pakistan's bilateral trade with its partners. Economic size was found to be positively related to bilateral trade when Pakistan's GDP increases, its total trade with its trading partners will increase. 
Though a very rich literature is available on the estimation of bilateral trade through the gravity model, very little work has been done on Pakistan's bilateral trade with SAARC countries. Bearing in mind the above literature, our research paper can contribute in several ways to the existing literature. First, we analyzed Pakistan's bilateral trade with all SAARC member countries. Previous researchers took into account only the major countries of the region and ignored small the countries. Second, we applied three different techniques for our estimation. Most researchers used a single estimation technique for analysis.

\section{Research Methodology}

The research methodology is a strategic plan through which we can reach our specified objectives. This plan is explained step by step in this chapter.

\section{The universe of the study}

The study has selected the SAARC region to estimate Pakistan's bilateral with the member countries. The area consists of eight countries: Afghanistan, Sri Lanka, Bhutan, Nepal, Bangladesh, India, the Maldives, and Pakistan. This area was chosen because the world largest market (India) lies next to Pakistan, and they share a long border. Similarly, Pakistan and Afghanistan share a long border and have historical trade relations. Other countries in the region also have close trade terms with Pakistan. Though Nepal, the Maldives, and Bhutan are small economies in the region, Pakistan has the chance to improve trade relations and extend the range of exports to these countries.

\section{Data sources}

For our estimation, a panel data set is used ranging from 2003 to 2016. All the data are taken on a yearly basis. Countries' individual and bilateral imports and exports data are taken from the International Trade Center (ITC), based on UN Comtrade statistics (2017). Data on macroeconomics variables (population, RGDP, and exchange rate) are obtained from the World Development Indicators (WDI 2017). Data on the distance between trade centers (normally capital cities) are taken and calculated from online Great Circle Distance. All the data are converted into US\$ million. Data on the populations for all countries are also presented in millions. 


\section{Model specification and theoretical framework}

Under this heading, the general framework of the gravity model is developed to analyze Pakistan's bilateral trade. It will facilitate the researcher in explaining the performance of $N$ cross-section units ( $i$ and $j=1,2,3, \ldots, N$ ) in $T$ years $(t=1,2,3 \ldots, \mathrm{T}$ ). The fundamental structure of the regression model is outlined below:

$$
Y_{i t}=\alpha+X_{i t} \beta_{i}+\varepsilon_{i t}
$$

Where $Y_{i t}=$ dependent variable or regressand. $\mathrm{i}=$ cross-section measurement for each individual country. $\mathrm{t}$ =time series measurement of the data. $\alpha=$ intercept (indicating countries' fixed effects). $\beta_{i}=$ slope or coefficient. $X_{i t}=$ independent variable (showing variation for country $\mathrm{i}$ in time period $\mathrm{t}$ ). $\varepsilon_{i t}=$ error term. The values of the fixed intercept, time variation and the coefficients or slope $\left(\beta_{i}\right)$ remain different for each country. The insertion of time trends and fixed-effects in the model enable the researcher to find out the role of the omitted variables in the long run (Sakyi 2011).

The gravity model of trade has become more important in recent years in international trade. It was used for the first time by Tinbergen (1962) and Pöyhönen (1963) for empirical analysis. In accordance with Newton's law of universal gravitation i.e., two items attract each other in proportion to their masses and inversely proportional to their distance, two countries will trade with each other according to their GDP sizes and proximity.

Krugman et al. (2012) are of the opinion that the gravity model is applicable in two-sided trade because high-income countries spend a huge share of their income on imports and attract other countries to purchase goods from them because they have a large variety of goods and have a vast home market. So, the larger the economy, the larger the trade. Krugman et al. (2012) also mentioned other factors that cause bilateral trade, but these factors fail to operate because of distance. Hence, when two countries are located far away from one another, their transportation cost will begin to increase, and trade volume will decrease. In such a case, both countries will lose the gains from bilateral trade.

The customized structure of Newton's law of universal gravitation is presented in the following functional shape.

$$
T T_{i j t}=\gamma\left(\frac{G D P_{i t}^{\beta_{1}} \times G D P_{j t}^{\beta_{2}}}{D_{i j}^{\beta_{3}}}\right)
$$

Where $\gamma=$ gravitational constant, $T T_{i j t}=$ volume of total bilateral trade (the summation of imports and exports), $i j=$ respective countries, and $t=$ time period. GDPs $=$ economic sizes of country $i$ and country $j$. $D_{i j}=$ distance between two trading countries (normally between capital cities). $\beta_{i}=$ coefficients $\left(\beta_{1}, \beta_{2}\right.$ and $\left.\beta_{1}\right)$ to be estimated. 
Taking the natural log of both sides of equation (3.2), the gravity equation looks like:

$$
\ln T T_{i j t}=\alpha+\beta_{1} \ln G D P_{i t}+\beta_{2} \ln G D P_{j t}-\beta_{3} \ln D_{i j}+\varepsilon_{i j t}
$$

Where $\ln =$ natural $\operatorname{logarithm}, \alpha=\log \gamma$, and $\varepsilon_{i j t}=$ the disturbance term or white-noise error term After applying natural log to the variables, the coefficients represent elasticities of independent variables in bilateral trade flows.

From the previously reviewed literature, it can be concluded that there are many other elements that are responsible for bilateral trade flows, but they are not plotted in the above equation. For the current study, the basic gravity model is enlarged with some other variables that hamper or promote bilateral trade.

The augmented gravity model developed for the current study is of the form:

$$
\begin{aligned}
& \ln T T_{i j t}=\alpha+\beta_{1} \ln \left(R G D P_{i t} * R G D P_{J T}\right)+\beta_{2} \ln \left(P O P_{i t} * P O P_{j t}\right)+ \\
& +\beta_{3} \ln E X R_{i j t}+\beta_{4} \ln D I S T_{i j}+\beta_{5} \ln C B O R_{i j}+\beta_{6} \ln C L A N G_{i j}+U_{i j t}
\end{aligned}
$$

The same equation (3.4) can be written as:

$$
\begin{gathered}
\ln T T_{i j t}=\alpha+\beta_{1} \ln R G D P_{i j t}+\beta_{2} \ln P O P_{i j t}+\beta_{3} \ln E X R_{i j t}+ \\
+\beta_{4} \ln D I S T_{i j}+\beta_{5} \ln C B O R_{i j}+\beta_{6} \ln C L A N G_{i j}+U_{i j t}
\end{gathered}
$$

where, $T T_{i j t}=$ total trade volume between country $i$ and country $j$ in time period $t$. $R G D P_{\mathrm{ijt}}=$ the product of Real Gross Domestic Product of country $i$ and country $j$ in period t. $P O P_{i j t}=$ the product of the population of country $i$ and country $j$ in time period $t . E X R_{i j t}=$ bilateral exchange rate between country $i$ and country $j$ in time period $t . D I S T_{i j}=$ distance between country $i$ and country $j$. The dummy variables of the study are: $C B O R=$ Common Border (which takes the value of ' 1 ' if the border is common, ' 0 ' otherwise) CLANG= Common Language (which takes the value of ' 1 ' if there is a common language, ' 0 ' otherwise) $\alpha=$ intercept, $U_{i j t}=$ omitted variables or unobserved factors that influence bilateral trade, and $\beta_{i}=$ coefficients $\left(\beta_{1}, \beta_{2}, \ldots, \beta_{6}\right.$ represent elasticities of variables).

\section{Analytical techniques}

The Analytical Techniques are the methods through which we enumerate the level of bilateral trade between Pakistan and the SAARC countries. These techniques include pooled OLS, fixed effects, and random effects. All these techniques are explained in the coming sections. 


\section{Pooled Ordinary Least Squares (OLS)}

The easiest technique for panel data estimation is the pooled ordinary least square (OLS) technique. It ignores the panel format (time and space dimensions) of the data and merely applies the typical OLS regression technique. The pooled OLS estimator can be written as:

$$
Y_{i t}=\alpha+X_{i t} \beta_{i}+\mu_{i t}
$$

Where $Y_{i t}=$ the dependent variable for country $i$ in time period $t . \alpha=$ intercept. $X_{i t}=1 \times \mathrm{K}$ vector of independent variables for country $i$ in time period $t . \beta_{i}=\mathrm{K} \times 1$ vector of coefficients, and $\mu_{i t}=$ the error or disturbance term of country $i$ in time period $t$. This technique is based on the assumption that the intercept $(\alpha)$ and all the parameters $\left(\beta_{i}\right)$ are equal for all countries individually across time, and that $\mu_{i t} \sim i i d\left(0, \sigma^{2}\right)$ for all $i$ and $t$. It implies that there is no autocorrelation, and the error terms are homogenous for each individual country $i$ during time period $t$.

\section{Fixed Effects Estimator}

It is a well-known reality that every individual cross-sectional component has several unique properties. The intercept of a fixed-effects equation varies among different individual units, but the same intercept remains constant (no variations) over time. While estimating the FEM, the disturbance term $\mu_{i t}$ is divided into two parts, one is component-specific and the other is the time-specific element. The summation of intercept ${ }^{\alpha}$ and specific disturbance term $\varepsilon_{i t}$ constitutes:

$$
\mu_{i t}=\alpha+\varepsilon_{i t} .
$$

Therefore the estimated fixed effect model (FEM) can be written as:

$$
Y_{i t}=X_{i t} \beta_{i}+\alpha_{i}+\varepsilon_{i t} \quad \varepsilon_{i t} \sim \operatorname{iid}\left(0, \sigma^{2}\right)
$$

The term $\alpha_{i}=$ the fixed parameter, that is to be estimated. Dummy variables are incorporated for every cross-sectional component during the estimation process. This procedure is known as the Least Squares Dummy Variables (LSDV) method. The estimation of the fixed effect model (estimators) helps to remove the endogeneity problem from the OLS regression model. Otherwise, it will give spurious results (Roy \& Rayhan 2011).

On the other hand, the random-effects model (REM) is based on the assumption that individual effects (heterogeneity) are separately divided between the disturbance term $\left(\varepsilon_{i t}\right)$ and the intercept $\left(a_{i}\right)$. It means that the disturbance term is not linked to the explanatory variables.

The REM can be shaped as:

$$
Y_{i t}=X_{i t} \beta_{i}+\mu+\alpha_{i}+\varepsilon_{i t} \varepsilon_{i t} \sim i i d\left(0, \sigma^{2}\right) \alpha_{i} \sim \operatorname{iid}\left(0, \sigma^{2}\right)
$$


Where $\alpha_{i}+\varepsilon_{i t}$ is considered to be an error term that consists of two elements; one is the individual specific element (time-invariant) and the other is a mixture of cross-section and time series error elements. The benefit of the REM is that it takes into account the impacts of time-invariant variables which are not included in the process of the fixed effect estimation process.

To make a selection between the two models (fixed and random), we apply the Hausman test. The Hausman test decides which model is suitable for estimation, the fixed effects model, or the random-effects model. We set the null hypothesis as: the random effect model is best for estimation. The alternative hypothesis is: the fixed-effects model is best for estimation. If we accept the null hypothesis, then we conclude that the random effect model is reliable for estimation. Conversely, if we accept the alternative hypothesis then we conclude that the fixed effect model is favorable for estimation.

\section{Trade potential concept and methodology}

The idea of trade potential is very common and widely used in studying international trade. Usually, two methods are used to estimate the trade potential of a country. One is the ratio method, and the other is the absolute difference method.

In the ratio method, the ratio of predicted trade and actual trade $(\mathrm{P} / \mathrm{A})$ is calculated. The predicted $(\mathrm{P})$ value means the estimated value of the dependent variable, while the actual (A) value means countries' actual trade with partner countries. The ratio (P/A) indicates trade potential and future trade direction of the country. If the value of $\mathrm{P} / \mathrm{A}$ is more than unity, it means that the home country has the potential to develop trade relations with partner countries.

In the second method, the absolute difference between the predicted and actual values (P-A) is used to calculate trade potential. A positive value indicates that the home country has the opportunity to increase its trade with the partner country, while a negative sign indicates that the home country has exceeded its trade potential with a particular trading country. In this study, the ratio method (P/A) will be applied to categorize those countries with which Pakistan has the potential to expand its trade.

\section{Results and Discussion}

The main theme of this chapter is to present and discuss the empirical findings of the study. In the first section, descriptive statistics are calculated. In the second section, the augmented gravity model is estimated, and the preliminary results are obtained through the fixed-effects (FE), random-effects (RE) and pooled OLS estimators. In the last section, the trade potential of Pakistan is calculated. 


\section{Descriptive statistics}

Descriptive statistics provide information about the nature of data used for analysis by measuring variations in the data. Normally, the mean and median are used to measure the central tendency of the variables. The mean values of every variable are bigger than the values of the median. It indicates that all the variables included in the current study are positively skewed. Dispersion in the data is shown by maximum and minimum values and standard deviation. From the values of standard deviation, it has been observed that $P O P_{i}$ (the population of Pakistan) has the smallest variations whereas the $R G D P_{j}$ (the RGDP of the partner country) has the greatest variation. The same is observed from the minimum and maximum values (Table 1). Now, we go forward with the position that all the variables in the study are adequately normal.

Table 1. Descriptive statistics

\begin{tabular}{|l|c|c|c|c|c|c|}
\hline Variables & Mean & Median & Maximum & Minimum & Std. Dev. & Obs. \\
\hline$T T_{i j t}$ & 583.504 & 270.557 & 2859.824 & 0.009 & 773.069 & 98 \\
\hline$R G D P_{i t}$ & 177489.1 & 176004.2 & 227747.9 & 129748.8 & 27340.90 & 98 \\
\hline$R G D P_{j t}$ & 261020.5 & 19245.61 & 2464933 & 888.427 & 586244.8 & 98 \\
\hline$P O P_{i t}$ & 169.5010 & 168.804 & 193.203 & 147.7034 & 14.225 & 98 \\
\hline$P O P_{j t}$ & 206.859 & 25.9170 & 1324.171 & 0.304 & 419.275 & 98 \\
\hline EXR $_{i j t}$ & 5135.157 & 4338.572 & 15252.46 & 739.225 & 3140.125 & 98 \\
\hline DIST $_{i j}$ & 1784.286 & 1731.000 & 3285.000 & 367.000 & 1029.636 & 98 \\
\hline
\end{tabular}

Note: Results are obtained by Eviews9, using panel data set from 2003-2016

Sources: World Development Indicators (WDI 2017) and the International Trade Center (ITC 2017).

\section{Results of the Augmented Gravity Model}

Starting with the pooled OLS results, the coefficients of all straight gravity variables $\left(\right.$ RGDP $_{\mathrm{ijt}}$ and distance) are significant and have predetermined signs. The empirical results indicate that a one percent increase in RGDPs will result in a 0.74 percent increase in Pakistan's bilateral trade. In contrast, the impact of the distance variable is found to be negative. A one percent increase in distance will reduce bilateral trade by 0.16 percent. It means that the greater the distance between Pakistan and its trading partner, the smaller the trade flow between them will be. The coefficient of the population is found to be negative. A one percent increase in population will decrease the trade volume by 0.36 percent. The impact of the real bilateral exchange rate is also observed to be negative. A depreciation of the local currency (Pakistan) in terms of the partner currency will increase trade between them. The dummy variables (common border and common language) are significant and have a positive impact on Pakistan's bilateral trade volume. 
Table 2. Results of Augmented Gravity

\begin{tabular}{|c|c|c|c|}
\hline $\begin{array}{l}\text { Estimated } \\
\text { Method }\end{array}$ & Pooled OLS Model & Fixed Effects Model & Random Effect Model \\
\hline \multirow[b]{2}{*}{$\begin{array}{l}\text { Independent } \\
\text { variables }\end{array}$} & $\operatorname{lnTT}$ & InTT & InTT \\
\hline & $\begin{array}{l}\text { Coefficient } \\
\text { P-value }\end{array}$ & $\begin{array}{l}\text { Coefficient } \\
\text { P-value }\end{array}$ & $\begin{array}{l}\text { Coefficient } \\
\text { P-value }\end{array}$ \\
\hline Constant & $-0.186^{*}(0.096)$ & $-0.748 *(0.061)$ & $-0.186^{* *}(0.013)$ \\
\hline $\ln R G D P_{i j t}$ & $0.742^{* *}(0.023)$ & $1.046^{* * *}(0.001)$ & $0.742^{* *}(0.045)$ \\
\hline $\ln P O P_{i j t}$ & $-0.359(0.230)$ & $-1.934^{* *}(0.040)$ & $0.359 *(0.072)$ \\
\hline $\ln E X R_{i j t}$ & $-0.491^{*}(0.102)$ & $-0.914^{* *}(0.037)$ & $-0.491^{* *}(0.012)$ \\
\hline $\operatorname{lnDIST} T_{i j}$ & $-0.156^{* *}(0.015)$ & $-0.837^{* * *}(0.004)$ & $-0.156(0.121)$ \\
\hline $\operatorname{InCBOR}$ & $2.417^{* * *}(0.004)$ & $-1.236^{* *}(0.015)$ & $2.417^{* * *}(0.007)$ \\
\hline $\operatorname{lnCLANG}$ & $0.405^{*}(0.088)$ & $0.271(0.304)$ & $0.405^{*}(0.064)$ \\
\hline$R^{2}$ & 0.696 & 0.860 & 0.646 \\
\hline Adjusted $R^{2}$ & 0.622 & 0.845 & 0.622 \\
\hline Hausman [x2] & & & $682.410(0.000)$ \\
\hline Durbin-Watson & 2.33 & 1.98 & \\
\hline
\end{tabular}

Note: ${ }^{* * *},{ }^{* *}$ and ${ }^{*}$ indicate significance level at 1\%, 5\% and $10 \%$ respectively. Results are obtained by Eviews9, using panel data set from 2003-2016.

Source: World Development Indicators (WDI 2017) and the International Trade Center (ITC 2017).

The major drawback of the pooled OLS technique is that it ignores the composition of time and space dimensions (panel structure) of the pooled data and only estimates the standard OLS regression model. This creates a serial correlation problem in the data and bypasses the effects of ignored heterogeneity on the volume of bilateral trade. To handle this problem, the researchers also estimated fixed-effects (FE) and random-effects (RE) models.

The empirical results of the Hausman test indicate that the null hypothesis of the random effects is strongly rejected, as the coefficient value of the Hausman test $=682.410$ and the $p$-value $=0.000$. So it was decided that the fixed effect (FE) model is suitable for measuring Pakistan's bilateral trade. Thus, the remaining discussion of this section is restricted only to the results of the gravity model of trade based on the fixed-effects estimation technique.

The empirical results of the gravity model, estimated through the fixed-effect method, indicate that the RGDPs of Pakistan and the partner country (the product of RGDPs) have a positive and significant impact on the total bilateral trade volume of Pakistan. A one percent increase in economic masses (RGDPs) of both countries will increase the trade volume by approximately 1.05 percent (Table 2 ). The results clearly follow the theoretical foundation of the gravity model. As the RGDP of Pakistan increases, it will export more commodities to the partner country. On the other hand, if the RGDP (economic mass) of the partner country increases, the people of that country (country $j$ or partner country) will import more commodities from Pakistan according to their needs. To generalize the results, Pakistan has an opportunity to extend 
her trade with countries that have higher incomes. The same conclusion was reached by Sokchea (2006), Chan-Hyun (2005) and Turkcan (2005).

Population is used as a proxy for market size. According to gravity theory, as the market size expands, the trade volume of a country also expands, ceteris paribus. Unfortunately, the empirical results of the study are against the theoretical background of the gravity theory. The product of the population coefficient is found to be significant but, surprisingly, to have a negative sign (-1.93). The estimated results suggest that a one percent increase in population will reduce the trade volume of Pakistan by 1.93 percent. This decline in the bilateral trade flows can be justified, as all the SAARC member countries, including Pakistan, are developing economies and their populations are still at the dynamic stage. Most domestically produced goods are utilized by the local population. This strongly recommends the reality of the absorption effect of the rising population. As most goods are sold in the home markets due to absorption capacity, fewer goods are left for export. As a result, bilateral trade volumes decline. These results are in line with Oguledo and Macphee (1994).

The exchange rate measures the value of the local currency in terms of foreign currency. The empirical results of the gravity model suggest that instability in the exchange rate has a negative relationship with bilateral trade. The coefficient of the exchange rate has a negative sign $(-0.91)$, which implies that a one percent devaluation in Pakistan's currency will boost her trade by 0.91 percent and vice versa, ceteris par$i b u s$. If the currency depreciates, net exports increase because they are now relatively cheaper, and imports decrease because they are expensive. If the currency appreciates, exports decrease because of its expensiveness in terms of foreign currency. This theoretical justification of the exchange rate is in line with the findings of Kandilov (2008), Cho et al. (2002), and Eichengreen and Irwin (1995).

The distance variable is incorporated as a proxy for transportation costs. The distance coefficient is found to be negative and significant. It implies that a $1 \%$ increase in distance between two economic centers will lead to a decrease in total bilateral trade by approximately $0.84 \%$. This perception clearly satisfies the theoretical foundation of distance in gravity theory. The results can be explained as: the further away from Pakistan the country is, greater the transportation costs will be and hence the smaller the trade activities. The outcome of the current study follows the results of Gul and Yasin (2011), Achakzai (2006), and Buch et al. (2003).

The term "common border" is used for border adjacency. Surprisingly, the coefficient of the common border is found with a negative sign i.e. approximately -1.24 . These empirical results imply that Pakistan's bilateral trade is $1.24 \%$ lower with neighboring countries (India and Afghanistan) compared to other SAARC countries. In fact, these results contradict the theory and common perception. The reasons for this contradiction are very clear. Trade between Pakistan and India is limited because of political divergence. Moreover, historical disputes like the Kashmir issue, two wars (1965 and 1971) between the two countries, and continuous tensions on the line of control (LOC) are the key factors that impede bilateral trade volumes between the two 
neighboring countries. Similarly, trade between Pakistan and Afghanistan is not encouraging. Terrorism is a common issue in both countries. Moreover, mistrust and misunderstanding from both sides negatively affect their trade. This perception is relevant to the findings of Rahman (2005).

The role of language is very important in determining trade between the two countries. The coefficient of the common language is positive (0.27), but it is not significant (Table 2). The result implies that the bilateral trade flow of Pakistan is $0.27 \%$ greater with those countries that have a common language than the other countries of SAARC. The coefficient value of a common language is very small, meaning that its impact on Pakistan's exports is nominal. The same opinion was expressed by Gul and Yasin (2011).

Finally, the values of $\mathrm{R}^{2}$ and adjusted $\mathrm{R}^{2}$ are 0.86 and 0.84 , respectively. It shows that $86 \%$ of the total bilateral trade between Pakistan and SAARC countries is explained by our estimated gravity variables. For the remaining $14 \%$ discrepancy, there may be some other variables which are not included in the model. The value of the Durbin-Watson D-test is equal to 1.98 , which is closer to two. So, it is assumed that there is no first-order autocorrelation, either positive or negative, among the selected variables.

\section{Pakistan's Trade Potential}

After estimating the gravity models, we are in a position to calculate the trade Pakistan's potential with the SAARC countries. As mentioned above, the findings of the gravity models based on the fixed-effects estimator are quite reliable and follow the theoretical background of the gravity model. In light of these findings, we estimate the trade potential of Pakistan across territorial borders.

Table 3. Trade Potential of Pakistan with SAARC Region

\begin{tabular}{|l|c|c|c|}
\hline \multicolumn{1}{|c|}{ Country Name } & P/A (2003-2007) & P/A (2008-2012) & P/A (2013-2016) \\
\hline India & $1.451^{*}$ & $1.318^{*}$ & $1.315^{*}$ \\
\hline Sri Lanka & $1.379^{*}$ & $1.286^{*}$ & $1.308^{*}$ \\
\hline Bangladesh & $1.712^{*}$ & $1.522^{*}$ & $1.506^{*}$ \\
\hline Nepal & $4.755^{*}$ & $9.477^{*}$ & $14.557^{*}$ \\
\hline Bhutan & $2.895^{*}$ & $1.404^{*}$ & $1.681^{*}$ \\
\hline Afghanistan & $1.037^{*}$ & $0.921^{* *}$ & $0.963^{* *}$ \\
\hline Maldives & $0.588^{* *}$ & $0.671^{* *}$ & $0.574^{* *}$ \\
\hline
\end{tabular}

Note: * shows the highest trade potential and ${ }^{* *}$ shows the exhausted trade potential. The results are obtained by Eviews9, using panel data set from 2003-2016.

Sources: World Development Indicators (WDI, 2017) and the International Trade Center (ITC, 2017).

According to the estimated results, Pakistan has a great deal of trade potential with all SAARC countries except for the Maldives and Afghanistan. Pakistan has the greatest trade potential with Nepal, as the ratio of predicted values and actual values $(P / A)$ 
is at the highest level in the last four years (2012 to 2016). Though the Nepalese economy is heavily dependent on the Indian economy and its trade flow is mainly with India, Pakistan has the highest trade potential with Nepal. Pakistan and India are the two major players of the SAARC region. India has a very wide market and Pakistan can extend its trade with India if they solve their disputes peacefully.

Similarly, Bangladesh and Sri Lanka are the two major economies of SAARC. Pakistan has very close trade relations with both countries, especially with Sri Lanka. There is an opportunity for Pakistan to strengthen these relations in the future. Pakistan had the maximum trade potential with Bhutan from 2003 to 2007. However, that trade potential still exists and Pakistan can expand its trade with Bhutan in the future.

Afghanistan and Pakistan share long border. Pakistan had a trade potential with Afghanistan from 2003 to 2007, as the predicted trade was greater than the actual trade $(\mathrm{P} / \mathrm{A}>1)$ during this period. However, now, Pakistan's actual trade is greater than the predicted trade, as the ratio is less than one $(\mathrm{P} / \mathrm{A}<1)$ in recent years of the study period. Pakistan has exhausted its trade potential with the Maldives (Table 3).

\section{Conclusion}

The study concentrates on bilateral trade flows between Pakistan and SAARC countries within the framework of the gravity model using a panel data set for the period 2003 to 2016. The estimation process used several econometric techniques like pooled OLS, and fixed-effects and random-effects estimation models. The empirical findings of the study indicate that the gravity model of trade is a very useful tool for measuring Pakistan's bilateral trade flows. The estimated coefficients of the basic gravity variables (RGDPs and distance) are found to be strongly consistent with the theoretical foundation of the gravity model. In particular, Pakistan's total bilateral trade volume with the SAARC region considerably increases with the expansion in the real gross domestic product (RGDPs) and diminishes with every increase in distance. The impact of population on bilateral trade was found to be significant but with a negative sign. This confirmed the theory of absorption effect of a rising population on bilateral trade. The coefficient of the bilateral exchange rate was found to be negative, which means that devaluation in Pakistani currency will boost its exports and vice versa. A common border has a negative impact on Pakistan's bilateral trade flows. Pakistan shares borders with India and Afghanistan, but it still has nominal trade relations with these two countries. Civil war and terrorism in Afghanistan, and political and military conflicts with India are the main factors that impede Pakistan's bilateral trade with these two countries. Lastly, a common language (official or commercial) was found to be expansionary in its effects. Though its coefficient is very small, its impact is significant. From the analysis of trade potential, it was concluded that Pakistan has maximum trade potential with all SAARC member countries except the Maldives and Afghanistan. 


\section{References}

Achakzai, J.K. (2006), Intra-ECO Trade: A Potential Region for Pakistan's Future Trade, "The Pakistan Development Review", 45 (3), pp. 425-437.

Akram, A. (2013), Pak-SAARC Intra-industry Trade, PIDE Working Papers, 93.

Buch, C.M., Kleinert, J., Touba, F. (2003), The Distance puzzle: On the interpretation of the distance coefficient in the Gravity equations. Kiel Working Paper No. 1159.

Chan-Hyun S. (2005), Does the gravity model explain South Korea's trade flows?, "The Japanese Economic Review", 56 (4), pp. 417-430.

Cho, G., Sheldon, I., McCorriston, S. (2002), Exchange Rate Uncertainity and Agricultural Trade. "American Journal of Agricultural Economics", 84, pp. 934-942.

Eichengreen, B., Irwin, D. (1995), Trade blocs, currency blocs and the reorientation of world trade in the 1930s, "Journal of International Economics", 38, pp. 1-24.

Gul, N., Yasin, M. (2011), The Trade Potential of Pakistan: An Application of the Gravity Model. "The Lahore Journal of Economics”, 16, pp. 23-62.

Hassan, R., Rehman, S. (2015), Economic Integration: An Analysis of Major SAARC Countries, "A Research Journal of South Asian Studies”, 30, pp. 95-105.

Hussain, H. (2017), Globalization and Gravity Model of Trade of Pakistan- A PPML Estimator Analysis, "Management and Administrative Sciences Review", 6, pp. 15-27.

Kandilov, I.T. (2008), The Effects of Exchange rate Volatility on Agricultural Trade, "American Journal of Agricultural Economics", 90, pp. 1028-1043.

Kaur, S., Nanda, P. (2010), India's Export Potential to Other SAARC Countries: A Gravity Model Analysis, "Journal of Global Economy”, 6 (3), pp. 167-184.

Oguledo, V.I., MacPhee, C.R. (1994), Gravity Models: a reformulation and an application to discriminatory trade arrangements, Applied Economics, 26, pp. 107-120.

Panda, R., Sethi, M., Kumaran, M. (2016), A Study of Bilateral Trade Flows of China and India, "Indian Journal of Science and Technology", pp. 1-7.

Poyhonen, P. (1963), A Tentative Model for the Volume of Trade between Countries, Weltwirtschaftliches Archiv, 90, pp. 93-100.

Rahman, M. (2005), The Determinants of Bangladesh's Trade: Evidence from the Generalized Gravity Model, Working Paper No. 3, University of Sydney, School of Economics.

Roy, M., Rayhan, I. (2011), Trade Flows of Bangladesh: A Gravity Model Approach, "Economics Bulletin", 31 (1), pp. 950-959.

Sakyi, D. (2011), Economic Globalisation, Democracy and Income in Sub-Saharan Africa: A Panel Cointegration Analysis, Proceedings of the German Development Economics Conference, Berlin 2011, No. 72.

Sherif, S., Fantazy, K. (2013), Factors Influencing Export in Bilateral Trade, "International Journal of Management, Economics and Social Sciences”, 2, pp. 12-27.

Shujaat, A. (2015), Economic Survey of Pakistan, (2015-16) Islamabad, Ministry of Finance, Government of Pakistan.

Sokchea, K. (2006), An analysis of Cambodia's Trade Flows: A Gravity Model, Working Paper Series, 21464, pp. 1-24.

Tinbergen, J. (1962), Shaping the World Economy: Suggestions for an International Economic Policy. New York: Twentieth Century Fund, 1962. 
Turkcan, K. (2005), Determinants of Intra-industry Trade in Final goods and Intermediate Goods between Turkey and Selected OECD Countries, Ekonometri ve Istatistik Say, 1, pp. 20-40.

Wang, J. (2016), Analysis and Comparison of the Factors Influencing Worldwide Four Kinds of Vegetable Oil Trade: Based on Gravity Model, "Modern Economy", 7 (2), pp. 173-182.

\section{Streszczenie}

\section{Zastosowanie modelu grawitacyjnego do oszacowania bilateralnej wymiany handlowej Pakistanu z krajami SAARC}

W artykule podjęto próbę oszacowania wielkości bilateralnej wymiany handlowej Pakistanu z krajami SAARC przy użyciu grawitacyjnego modelu handlu. Niniejsze badanie panelowe obejmuje okres od 2003 do 2016 r. Wyniki empiryczne uzyskano za pomocą metody najmniejszych kwadratów (pooled OLS), metody efektów stałych i estymatorów efektów losowych. Z uwagi na wyniki testu Hausmana w pracy skoncentrowano się wyłącznie na ustaleniach modelu efektów stałych. Badania empiryczne wskazują, że zarówno PKB Pakistanu, jak i państwa partnerskiego, mają pozytywny wpływ na wielkość wymiany handlowej. Wielkość rynku ma negatywny wpływ na handel i jest to uzasadnione z uwagi na występowanie efektu absorpcji. Podobnie odległość i kurs wymiany są również ujemnie skorelowane z wielkością wymiany handlowej. Badanie wykazało, że pomimo wspólnej granicy wielkość wymiany handlowej Pakistanu z Indiami i Afganistanem jest bardzo niska. Wspólny język ma pozytywny, ale nieznaczny wpływ na wielkość wymiany handlowej Pakistanu. W artykule podjęto również próbę obliczenia potencjału handlowego Pakistanu. Wyniki tego badania wskazują, że Pakistan ma duży potencjał handlowy w relacjach ze wszystkimi krajami członkowskimi SAARC, z wyjątkiem Malediwów i Afganistanu.

Słowa kluczowe: bilateralna wymiana handlowa, wspólny język, kurs walutowy, model grawitacyjny, liczba ludności 